\title{
Becoming Automatous: Automata in The Old Curiosity Shop and Our Mutual Friend
}

\section{Katherine Inglis}

What are 'automata'? In nineteenth-century common usage, 'automata' meant 'machinery constructed to resemble human or animal actions'. ${ }^{1}$ The current $O E D$ definition expresses multiple contradictory meanings, including things with the power of spontaneous motion, mechanisms with concealed motive powers, and persons behaving mechanically without active intelligence. Thus, as Steve Connor has observed, 'automaton' is intrinsically ambiguous, signifying both 'directed and self-directed entities'.2 Over time, a word which originally meant 'self-moving' has 'accrued the meaning of an apparently self-directing process which in reality has its motion determined' ${ }^{3}$ An automaton is a mechanical dissembler, concealing its thesis and parading its antithesis, appearing to possess that which, by definition, it cannot autonomy.

In European philosophy this paradoxical figure has historically been associated with debates over free will and determinism, the relationship between the individual and the state, and the nature of human freedom, most notably in Descartes and La Mettrie's formulations of the boundaries of the human. ${ }^{4}$ The automaton has been used as an analogy for both normal and pathological behaviours, as a paradigm and a warning, as a benchmark against which humans are measured and found wanting and as the symbol of all that is reactive, affectless and inhuman. In the nineteenth-century, automata were prominent in materialist philosophies, reconfigurations of industrial and military systems, literature on the machinery question, physiological texts, and evolutionary debates. This versatile, unstable figure is a regular actor in Dickens's imaginative representations of the destabilisation of human agency. Its appearances are connected to, but not identical with, the idea of the prosthetic in Dickens's writing as formulated by Herbert Sussman and Gerhard Joseph, the 'fantastical [...] splice of the machine and the organic' that articulates the 'machine/body issues of [Dickens's] age' and also anticipates 'posthuman' anxieties of human agency. ${ }^{5}$ For Sussman and Joseph, Dickens's 'oscillation [...] between representing characters as self-acting "things" and as 
“people”, (i.e., as nineteenth-century liberal subjects moved by ethical will) registers a Victorian discursive practice wherein the boundary between the machine and the human tends to dissolve'. ${ }^{6}$ Sussman and Joseph's exemplary spliced figure is Captain Cuttle of Dombey and Son, a liberal 'fused subject' whose mechanical part is a tool and who is always in control of his 'prostheticized body', whereas this essay is concerned with a more violent relation between indistinct categories of things and people, where the human is vulnerable to mechanical impressions or is reducible to an organic machine. ${ }^{7}$ Automata are not as prominent in Dickens's writing as prosthetics, but when they do appear they register a particular form of dehumanisation, wherein the confusion of things and people encourages the destabilisation of human agency and the collapse of personal autonomy. In The Old Curiosity Shop (1840-41) and Our Mutual Friend (1864-65), Dickens merges the symbolic automaton of philosophy, physiology and industry with the toys and exhibition pieces of nineteenth-century popular culture, creating a liminal, pathological, distressed figure whose unstable autonomy casts doubt on the authenticity of the freedom of automatous (automaton-like) characters. The Old Curiosity Shop, which features a brief but significant cameo by an automaton, draws on the configuration of industrial subjectivity in contemporary writing on factory systems in its portrayal of Little Nell and Quilp’s mechanical affinities. In Our Mutual Friend musical automata and speaking machines are models for human degradation. In both novels, automatous humans appear to be autonomous self-movers, but are perhaps, like android automata, dissemblers performing an imperfect impression of human agency.

\section{I}

\section{The Popular Automaton}

The android writers and musicians created by Jacques Vaucanson and the Jaquet-Droz family in the eighteenth century feature prominently in histories of automata, cyborgs, and artificial life. Vaucanson's German flute-player and tabor-and-pipe player were notable for actually playing their instruments, rather than simulating the action of playing while a separate mechanism produced the melody. ${ }^{8}$ Henri-Louis Jaquet-Droz's

Katherine Inglis, Becoming Automatous: Automata in The Old Curiosity Shop and Our Mutual Friend

19: Interdisciplinary Studies in the Long Nineteenth Century, 6 (2008) www.19.bbk.ac.uk 
writer, draughtsman and harpsichord player (known as the Musicienne) were shown in London in 1776, and replicas were exhibited into the nineteenth mcentury. ${ }^{9}$ Like Vaucanson's musicians, both the Musicienne and the replica known as the Musical Lady genuinely played their instruments. ${ }^{10}$ A film clip of the Musicienne's performance can be viewed by clicking here: La Musicienne. ${ }^{11}$

Though Dickens could not have seen these androids, less complex android automata were popular in shows and exhibitions throughout the nineteenth-century. Automation was integral to many waxwork shows; automata were advertised at travelling fairs as 'moving waxworks' and 'mechanical composition figures', and moving waxworks were shown at Madame Tussaud's, Bartholomew Fair, and dedicated exhibitions. ${ }^{12}$ The 'mechanical figures' and 'fortune telling apparatus' mentioned by Henry Mayhew, shown by 'street showmen', would also have been automata. ${ }^{13}$ Later in the century, automata were used in ventriloquism shows. ${ }^{14}$

Though they appear less prominently in histories of automata than their glamorous musical counterparts, speaking machines were regarded seriously by contemporary commentators, for as Steven Connor explains, 'speech represented the ultimate challenge for the makers of automata, because speech was the most plausible proof that the automaton was truly self-moving, or even, as we might nowadays say, self-organizing'. ${ }^{15}$ Simple speaking machines were given human form early in the century. Johann Maelzel patented a speaking doll in 1824 that could say 'Maman' and 'Papa', and gave Baron Wolfgang von Kempelen's notorious chess-playing 'Turk' a mechanical voice, enabling it to declare 'échec et mat' when it won a game. ${ }^{16}$ On the first tour of its long career, this 'bagatelle' was accompanied by a speaking automaton that could produce vowel sounds and simple words, which Kempelen had entered for a competition held by the Academy of St Petersburg in 1779 for an invention capable of pronouncing the five vowels. Thomas L. Hankins and Robert J. Silverman cite accounts of an improved version of this machine which testify that it was able to articulate phrases such as 'Maman aimez-moi' and 'astronomie'. ${ }^{17}$ Charles Wheatstone made a copy of this automaton in order to 'analyse the production of vocal sounds in a

\section{Katherine Inglis, Becoming Automatous: Automata in The Old Curiosity Shop and Our Mutual Friend}

19: Interdisciplinary Studies in the Long Nineteenth Century, 6 (2008) www.19.bbk.ac.uk 
scientific way'. ${ }^{18}$ The young Alexander Graham Bell set out to build his own machine after seeing this demonstrated in $1863 .^{19}$

Perhaps the most impressive speaking automaton was Professor Joseph Faber's 'Euphonia' (see fig. 1), which was displayed in London in 1846 and eventually purchased by Barnum. $^{20}$ According to Hankins and Silverman, Bell also saw Euphonia in London in $1863 .{ }^{21}$ Alfred Chapuis and Edmund Droz describe an android automaton comprising a bellows, a tongue made of ivory to alter the pitch, an articulated mechanism to produce vowels and consonants, and a cavity to

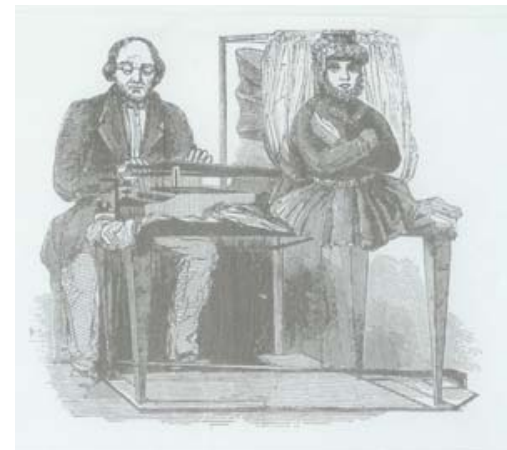

Fig. 1 Faber and his Euphonia produce nasal sounds. ${ }^{22}$ The android was in fact only half an android, a truncated 'Turkish' torso. ${ }^{23}$ The Illustrated London News reported that the machine could produce French, English, Latin, Greek and German sounds, whisper, laugh and even sing, implying that the machine was sufficiently versatile to truly replicate human vocal performance, depending 'upon the agility of the director in manipulating the keys'. ${ }^{24}$ However Euphonia's voice was apparently rather monotonous as its intonation could not be varied. ${ }^{25}$

A shift in the common understanding of what an automaton was took place through the century as the automata market expanded and diversified in response to new manufacturing techniques. ${ }^{26}$ The use of machines in toy and automaton manufacture shortened the time it took to cut out parts, so automata could be produced more quickly, in greater quantities and more cheaply. The expansion of automata production may also have been fuelled by the migration of expertise from other fields. ${ }^{27}$ New toy and automaton companies were established in Britain, France, Germany and the USA throughout the nineteenth century. ${ }^{28}$ According to Antonia Fraser the British market was geared towards 'inexpensive mechanical toys', particularly musical toys such as musical dolls, music boxes, and 'poupard' dolls. ${ }^{29}$ The first music boxes appeared early in the nineteenth century, and musical mechanisms were put into miniatures, furniture, toys and tableaux animés. ${ }^{30}$ Serial production of simple handle-operated music boxes in

Katherine Inglis, Becoming Automatous: Automata in The Old Curiosity Shop and Our Mutual Friend

19: Interdisciplinary Studies in the Long Nineteenth Century, 6 (2008) www.19.bbk.ac.uk 
the 1860s coincided with improvements in the mechanism of musical automata that ensured the automaton's gestures coincided with its music, thus masking the sound of the mechanism and making the automaton more convincing. ${ }^{31}$ In the eighteenth century a musical automaton would have meant an android flautist or harpsichord player, but in the nineteenth century it could mean any number of musical mechanisms and toys.

\section{The Factory-Automaton}

Historians of technology in the nineteenth and twentieth centuries have described a complementary relationship between automata and industrial technology. ${ }^{32}$ Hal Foster's account of Vaucanson's second career as the Inspector of the Silk Manufactures, in which he invented a mechanical loom that was the basis for the Jacquard loom and designed a silk factory that anticipated the 'modern industrial plant', demonstrates the overlap between the histories of automata and industrialization. ${ }^{33}$ For Foster, Vaucanson's ‘automaton or machine-as-man announces the modern factory, the central site where man-as-machine, worker-as-automaton, is produced'. ${ }^{4}$ This radical reconfiguration of the human is both enabled by and modelled upon the automaton, which stands as the worker's mechanical doppelgänger in factory literature. In discussions of the factory in the 1830s and 40s, the factory space becomes a system, then an automaton-like organism, while the worker becomes a machine, then an automaton-component. Multiple, diffuse, and fragmented, this symbolic automaton is as significant an influence as the actual commodity on Dickens's material imagination in The Old Curiosity Shop, where machine-operatives are conflated with their machines, and more disturbingly, become fragments of the factory-automaton. Though Hard Times (1854) rather than The Old Curiosity Shop is the novel that springs to mind when thinking about Dickens's interest in factory conditions, The Old Curiosity Shop, published 1840-41, engages with contemporary factory literature in which the automaton plays a prominent role. ${ }^{35}$ Dickens creates mechanical and metallurgic characters throughout his career (for example, Bitzer, Wemmick, Pancks, Flintwinch

Katherine Inglis, Becoming Automatous: Automata in The Old Curiosity Shop and Our Mutual Friend

19: Interdisciplinary Studies in the Long Nineteenth Century, 6 (2008) www.19.bbk.ac.uk 
and Doyce, to name a few), but automatous entities are rare. ${ }^{36}$ The Old Curiosity Shop's automaton is connected to a distinct, hybrid subjectivity that is peculiar to its historical and political context.

In discussions of industrialization in the 1830s and 40s, the factory is imagined as a space of porous boundaries where subjectivity migrates between workers, machines, and the factory itself. Tamara Ketabgian characterises this continual renegotiation of industrial subjectivity as a 'border war' between the 'human and nonhuman, the animate and the inanimate, the organic and the fleshly', which produced multiple 'new, hybrid forms of humanness and nonhumanness, which emerge beside, between, and within machines'.37 Though Ketabgian demonstrates that these subjectivities were not necessarily abject (in Harriet Martineau's journalism superhuman female factory workers anticipate the enhanced humans of cyberpunk) the valorization of machines is generally achieved at the expense of workers' economic and psychological integrity. A peculiar adumbrated, subhuman machine-operative emerges in the factory literature of the 1830s that informs Marx's characterisation of postcapitalist production; in pre-capitalist production the automaton is the object of labour, but in post-capitalist production, the automaton becomes the subject and machineworkers become unconscious organs of the automaton. Ketabgian describes this industrial automatous hybrid elegantly as a 'foreshortened notion of the human', an 'industrial subject [who] emerges not as a complete body but as a prosthesis masquerading as a body'. ${ }^{38}$ The machine-operative is likened to an automatoncomponent in the work of both opponents and proponents of the factory system, most prominently in Andrew Ure's Philosophy of Manufactures (1835), which Maxine Berg has neatly described as an 'extraordinary and blatant panegyric in apology for the factory system', and in Peter Gaskell's counterblast to Ure, Artisans and Machinery (1863). ${ }^{39}$

Ure's perfect worker is a subordinate component of a greater organism, a leviathan factory-automaton:

I conceive that this title [factory], in its strictest sense, involves the idea of a vast automaton, composed of various mechanical and intellectual organs,

\section{Katherine Inglis, Becoming Automatous: Automata in The Old Curiosity Shop and}

19: Interdisciplinary Studies in the Long Nineteenth Century, 6 (2008) www.19.bbk.ac.uk 
acting in uninterrupted concert for the production of a common object, all of them being subordinated to a self-regulated moving force. ${ }^{40}$

It is easy to miss the worker in this famous passage. The workers are the intellectual organs', the organic counterparts to the 'mechanical organs', which are all subordinate to the factory-automaton, the agent and owner of subjectivity. Berg's suggestion that Ure's automaton-factory takes on 'distinctly mystical qualities' is not hyperbolic. ${ }^{41}$ It is a superhuman figure. Ure's representation of the relationship between workers and machines calls for an unbalanced symbiosis, in which the human is the subordinate organism and human agency is curtailed; self-will certainly has no place in his schema, for 'the more skilful the worker, the more self-willed and intractable he is apt to become, and, of course, the less fit a component of a mechanical system' ${ }^{42}$ For Ure, the harmonious factory closely resembled the organisation of an automaton and its workers consciously accommodated themselves to an automatous model of work. He declared that Arkwright's greatest triumph was the imposition of a new way of thinking about work on his employees, by 'training human beings to renounce their desultory habits of work, and to identify themselves with the unvarying regularity of the complex automaton'. 43

Peter Gaskell's critique of Ure's celebration of the factory worker's mechanisation describes the suffering of a physically and morally degenerate labour force consequent to its accommodation to the automaton model. Industrial development and 'the subjection of human power, as an agent of labour, to the gigantic and untiring energies of automatic machinery' had reduced the labourer to 'a mere watcher or feeder of his mighty assistant'. ${ }^{4}$

The labourer is indeed become a subsidiary to this power. Already he is condemned, hour after hour, day after day, to watch and minister its operations, - to become himself as much a part of its mechanism as its cranks and cog-wheels, - already to feel that he is but a portion of a mighty machine, every improved application of which, every addition to its Briareus-like arms, rapidly lessens his importance, and tends to drive him from a participation with it, as the most expensive and unmanageable part of its materials. $^{45}$

Katherine Inglis, Becoming Automatous: Automata in The Old Curiosity Shop and Our Mutual Friend

19: Interdisciplinary Studies in the Long Nineteenth Century, 6 (2008) www.19.bbk.ac.uk 
In classical mythology, Briareus was a giant with a hundred hands and fifty heads. ${ }^{46}$ Andrew Ure had nominated the automaton-factory 'the factory Briareus', but made no further comment on the potentially disturbing image. ${ }^{47}$ Gaskell's Briareus is a more threatening and monstrous figure, anticipating Marx's factory, the cyborg-like 'lifeless mechanism' of which the worker is a 'mere living appendage' ${ }^{48}$ For Gaskell, though not for Marx, this monstrosity extended from the automaton-factory to the machineoperatives, particularly the child workers, who he argued were in a very literal sense deformed and made monstrous by their automatous hybridity.

Gaskell described a non-specific pathology peculiar to machine-operatives, characterised by a 'slow and very protracted decline' and a general 'lessened vital energy'. ${ }^{49}$ It was exaggerated in child workers, whose development was disrupted and perverted by their working conditions; young workers' skeletons (which he significantly termed 'the mechanical apparatus') were liable to deformity consequent to extended periods of malnourishment and poor working and living conditions. ${ }^{50}$ Deformity manifested itself at maturity physically and morally. Gaskell's workers are stunted, enervated and sexually incontinent. They have 'pale and flaccid features, a stunted growth, very often tumid bellies, tender eyes, and other marks that the primce viæe have been permitted to go wrong'. ${ }^{51}$ These proto-Morlocks are 'sallow and pallid, with a peculiar flatness of feature', their 'stature' is 'low', their limbs are 'slender' and they move 'badly and ungracefully'. 52 The state of the female factory workers is particularly abject. The 'precociously-developed girls herding in town factories' display 'an absence of grace and feminine manners - a peculiar roughness of voice’ probably caused by 'too early sexual excitement' and are 'awkward and ungainly' and 'bony'. 53 Machine-work has rendered them abject and immoral, with pathognomonic signs legible on their bodies.

These 'foreshortened' automatous creatures would seem to stand as polar opposites to Little Nell, the innocent, graceful, undeveloped doll-like child. Yet Nell demonstrates a counterintuitive affinity with monstrous mechanical beings, is in theory the ideal factory worker, and comes perilously close to the factory-automaton — and by extension, to the possibility of a debased maturity.

Katherine Inglis, Becoming Automatous: Automata in The Old Curiosity Shop and Our Mutual Friend

19: Interdisciplinary Studies in the Long Nineteenth Century, 6 (2008) www.19.bbk.ac.uk 
III

\section{Industrial Nell}

When Little Nell invites Miss Monflathers and her schoolchildren to Mrs Jarley's waxwork exhibition, Miss Monflathers rebukes Nell for laziness. Nell’s occupation is less profitable, less edifying and less respectable than that of the machine-operative.

'Don't you feel how naughty it is of you,' resumed Miss Monflathers, 'to be a wax-work child, when you might have the proud consciousness of assisting, to the extent of your infant powers, the manufactures of your country; of improving your mind by the constant contemplation of the steam-engine; and of earning a comfortable and independent subsistence of from two-and-nine-pence to three shillings per week? Don't you know that the harder you are at work, the happier you are? ${ }^{54}$

Miss Monflathers is ventriloquising Ure, advertising the factory-life as that which is the most conducive to the happiness of the worker and the national interest. Her recommendation that Nell improve herself through the constant contemplation of the steam-engine overlaps with Ure's recommendation that workers 'identify themselves with the unvarying regularity of the complex automaton'. ${ }^{55}$ Dickens always regarded steam-engine contemplation with suspicion, as in 'The Amusements of the People', wherein he asserted that he would mistrust a young man who found all his amusement at the Polytechnic 'among cranks and cogwheels' ${ }^{56}$ Normal people cannot be satisfied by steam-engine contemplation as 'there is a range of imagination in most of us, which no amount of steam-engines will satisfy'.57 Much as Gaskell's children are foreshortened, the young man emerges from his mechanical education with a deficit of imagination. Constant contemplation of the steam-engine produces something approaching an automatous entity, which for Dickens, like Gaskell, is potentially abject. This is expressed in the automaton's brief cameo appearance in The Old Curiosity Shop.

Mrs Jarley’s defiant response to a dearth of customers and Miss Monflathers's scorn is to resurrect an old exhibit, an android automaton of the moving waxwork type:

Certain machinery in the body of the nun on the leads over the door was cleaned and put in motion, so that the figure shook its head paralytically all day long, to the great admiration of a drunken, but very Protestant, barber over the way (247).

Katherine Inglis, Becoming Automatous: Automata in The Old Curiosity Shop and Our Mutual Friend

19: Interdisciplinary Studies in the Long Nineteenth Century, 6 (2008) www.19.bbk.ac.uk 
The nun is a pathetic figure, perched ridiculously on the roof as an enticement to see the more edifying waxwork celebrities inside. Yet this comic machine points toward a serious threat to Nell's autonomy. Nell tends to acquire an air of the things she is surrounded by (effigies, curiosities, waxworks) and is according to Ure's thesis the ideal automaton-component, being young, female and unskilled. The hardworking paralytic nun anticipates the suffering, degraded beings Nell encounters on her journey through the industrial wilderness and gestures towards what Nell might have become had she pursued her ideal career. In his analysis of nineteenth-century female automata M. Norton Wise has shown how a stereotyped mechanistic female labouring body 'acquired something like the status of an unquestionable fact of nature' in a range of emergent sciences, connecting the classification of machines into dynamic engines that produced power and kinematic mechanisms that merely transmitted power, the gendered division of labour and status in the literature of political economy, and the association of repetitive, automatic functions with female traits and primitivism in experimental and evolutionary physiology. ${ }^{58}$ The nun's performance enacts the stereotype, resonating with the characterisation of female factory workers as docile, automatous figures in contemporary discussions of machine-work. As Wise explains, the division of machines into engines and mere mechanisms 'found ready extension to the organization of labor inside the factory itself, providing images for the differentiation of status and gender', so that in Britain 'women's work [...] was associated with repetitive mechanism, ${ }^{59}$ The nun is a model worker. It performs a limited series of movements 'all day long', just as the female machine-operative is compelled to repeat a sequence of movements through the working day. It embodies what would seem to be the obvious remedy for Nell's predicament, a career as a machine-operative, but it is also a warning of the consequences of becoming automatous. It recalls Gaskell's worker in its collection of symptoms, being weakened, dysfunctional, and paralytic. The machine is sick.

The paralytic nun stands in uneasy relation to the female automata most frequently encountered in literary criticism, the empowered, feminist cyborgs imagined by Donna Haraway, who find pleasure in the confusion of boundaries, and the elegant,

Katherine Inglis, Becoming Automatous: Automata in The Old Curiosity Shop and Our Mutual Friend

19: Interdisciplinary Studies in the Long Nineteenth Century, 6 (2008) www.19.bbk.ac.uk 
seductive figures described in cultural histories of automata, whose stereotypical 'feminine' movements (shy glances, ostentatious respiration and so on) are held by modern historians to reveal the artifice inherent in behaviours that were thought to be natural and authentic. ${ }^{60}$ By performing femininity so successfully (as contemporary responses testify), these automata effectively reveal the coding of feminine behaviour and so trouble the idea of an authentic 'feminine' identity. ${ }^{61}$ The paralytic nun, however, fails to adhere to either type, lacking the autonomy of the feminist cyborg and the ability of the beautiful dancers and pneumatic musicians to inspire an appropriate affective response in the (presumed male) viewer. As a performer of femininity, it fails abysmally: the nun can only twitch ineffectually, inspiring the drunken barber to discourse on 'the degrading effect wrought upon the human mind by the ceremonies of the Roman Church' rather than to admire the grace or ingenious mechanism of the female automaton (247). It is at best a parody of these feminine automata, a jerky, dysfunctional version of Madame Tussaud's beautiful 'breathing' waxwork, the 'Sleeping Beauty'. Its femininity has been compromised, its representation of elegance disabled, much as Gaskell held that the femininity and physical development of female machine workers were disrupted by the nature of their work. The nun represents a form of work that imprints a disfiguring mark on the body of the automatous worker, rendering her mechanistic and compromising her agency. Lingering in the company of machines, Nell discovers, causes one to diminish. She proves susceptible to the automatous environment in the course of her journey through the industrial landscape, but ultimately she rejects her mechanical potential by fleeing the town. The effort costs Nell her life, but enables her to retain her authenticity, preserving her from the automatous existence embodied by the nun.

The factory in The Old Curiosity Shop is scattered across a strange industrial landscape, a 'mournful place' composed of chimneys and engines (338). It is fragmented, tearing itself apart, yet seemingly infinite, endlessly repeated. Its mechanical and intellectual components, the machines and their operatives, are incoherent and distressed. As with Ure's description of the factory, it is difficult to distinguish the furious machines from their ragged attendants. This collective of

Katherine Inglis, Becoming Automatous: Automata in The Old Curiosity Shop and Our Mutual Friend

19: Interdisciplinary Studies in the Long Nineteenth Century, 6 (2008) www.19.bbk.ac.uk 
'strange engines spun and writhed like tortured creatures; clanking their iron chains, shrieking in their rapid whirl from time to time as though in torment unendurable' (339). Dickens likens 'the wrathful monsters' (the engines) to the workers in 'their wildness and their untamed air' (339).

The one generous worker Nell meets, who leads her to shelter in a steel foundry, resembles Gaskell's pathological type: weak, pallid, emaciated, yet possessed of a capacity for endurance that suits monotonous work:

The form was that of a man, miserably clad and begrimed with smoke, which, perhaps by its contrast with the natural colour of his skin, made him look paler than he really was. That he was naturally of a very wan and pallid aspect, however, his hollow cheeks, sharp features, and sunken eyes, no less than a certain look of patient endurance, sufficiently testified (332).

The worker's job is to mind the furnace. Dickens's portrayal of the furnace-tender at work moves towards Ure's characterization of the abstracted worker, lost in elevated thought. Ure attempted to counter the argument that the monotony of factory work would cause the labourer's mental stagnation, positing that artisans working within a division of labour system had to concentrate on their work to prevent errors, whereas unskilled machine-operatives were free to meditate and improve their minds, Monflathers-fashion, through machine-contemplation. ${ }^{62}$ Dickens's worker takes full advantage of this freedom, imagining the furnace to be his memory, tracing scenes in the flames. According to John Carey such imaginative 'fire watching' is a marker of virtue in Dickens's novels. ${ }^{63}$ However, when Nell wakes to find the worker 'in exactly the same attitude, looking with a fixed earnestness of attention towards the fire, and keeping so very still that he did not even seem to breathe', she fears that he has died in the night, suggesting that the worker's factory-enabled meditation is less a marker of virtue than pathognomonic (334). The furnace-tender may not strictly speaking be a machine operative, but his identity is, like Ure's operative's, wholly bound up in and constructed by the factory and projected onto a material substitute.

The factory recognises Nell as one of its own. There is something in her that reminds the furnace-tender of himself as a child, hence his decision to give her shelter by the furnace just as he found shelter there as an orphan:

\section{Katherine Inglis, Becoming Automatous: Automata in The Old Curiosity Shop and Our Mutual Friend}

19: Interdisciplinary Studies in the Long Nineteenth Century, 6 (2008) www.19.bbk.ac.uk 
When I saw you in the street tonight, you put me in mind of myself as I was after he [his father] died, and made me wish to bring you to the old fire. I thought of those old times again when I saw you sleeping by it (335-36).

Though she bears little resemblance to the shadowy 'giants' she glimpses in the foundry, Nell's fellowship with the furnace-tender is overt and is marked by her rapid development of the factory pathology. The first intimations of Nell's physical decline are made in the town, and crucially they make her resemblance to the enervated factory worker explicit. She suffers from joint pains (Gaskell's child workers were prone to skeletal distortions, particularly rickets), she is 'weak', her senses are numbed, she becomes hopeless, and loses her appetite (Gaskell's workers suffer from digestive problems) (340). Her vital energy lessens, her primce vice evidently goes wrong. Yet she demonstrates a capacity for endurance in her escape from the town that recalls the worker's surprising strength when he carried her 'as easily [...] as if she had been an infant' (332). Despite her fear of the town, Nell unconsciously accommodates herself to factory-life and rests as easily in the foundry as she does in her rural idyll. She finds peace before the furnace more easily than she did in Mrs Jarley's caravan, yielding to 'the drowsiness that came upon her, and, in the dark strange place and on the heap of ashes, slept as peacefully, as if the room had been a palace chamber, and the bed, a bed of down' (336). This recalls the earlier passage in which steel-workers slept and rested 'upon heaps of coals or ashes' (333). Nell never becomes mechanical and flees from the industrial area, but there is clearly potential for an automatous existence had she heeded Miss Monflathers. Her flight from the town is therefore perhaps as much a flight from this automatous possibility as it is from the temptation urban life exerts on her grandfather.

IV

\section{Clockwork Quilp}

Nell's automatous potential is counterintuitive. She embodies selflessness and the triumph of all that is human and sympathetic over the profit-driven spirit of the factory.

Katherine Inglis, Becoming Automatous: Automata in The Old Curiosity Shop and Our Mutual Friend

19: Interdisciplinary Studies in the Long Nineteenth Century, 6 (2008) www.19.bbk.ac.uk 
However Nell's automatous potential is supported by a series of mechanical and material connections: the furnace-tender's mannerisms resemble Daniel Quilp’s and the automaton nun's awkward mechanical simulation of vitality. In her nightmares, Nell recognizes Quilp's spectacular mechanical hybridity, dreaming that he is 'himself, Mrs. Jarley, wax-work, and a barrel organ all in one’ (213). Critical approaches to Quilp’s hybridity portray him as a transgressor of boundaries, 'an essentially ambiguous figure' for Michael Hollington, emblematic of the novel's '[collapse] of distinctions between characters and objects, human and inanimate matter' ${ }^{64}$ Such readings, though insightful, do tend to underestimate Quilp’s mechanical element. Paul Schlicke’s Quilp is a 'freak-show creature let loose', a semi-demonic hybrid of the underworld and the world of shows, whose ostentatious egotism and absolute freedom (from conscience, from responsibilities) is inherently antagonistic to 'mechanical rigidity'. ${ }^{65}$ However, as Nell suspects and the novel hints, Quilp’s exuberance is compromised, being mechanically predetermined: though Quilp’s energy is superficially more vital and appealing that Nell's anaemic purity, his vitality proves to be an inauthentic, automatous simulation of humanity that is contained and then terminated in brutal fashion. He is as much a clockwork villain as a pantomime ogre, an apt mechanical conduit for the nightmarish properties of the ostensibly benign clockwork frame of the novel: The Old Curiosity Shop was first published in Master Humphrey's Clock, the organising conceit of which was that Master Humphrey's tales were based on papers stored inside his grandfather clock. As John Bowen has shown, though Nell eventually emerges from the tomb-like environs of the Clock, the mournful concerns of the journal remain intimately connected to the novel. ${ }^{66}$ Nell is thus pursued by clockwork, encased in clockwork, and in danger of becoming mechanized herself: however, the novel's eventual annihilation of the automaton through Quilp's death is, I would suggest, symbolic of Nell's ultimately successful resistance to automatization.

Nell's instinctive reaction when the worker first appears is to scream and recoil. His abrupt appearance as 'a black figure which came suddenly out of the dark recess' closely resembles Quilp’s habit of bursting from concealed niches (331). In an earlier chapter, Quilp terrified Nell in the same way. 'There was an empty niche from which

Katherine Inglis, Becoming Automatous: Automata in The Old Curiosity Shop and Our Mutual Friend

19: Interdisciplinary Studies in the Long Nineteenth Century, 6 (2008) www.19.bbk.ac.uk 
some old statue had fallen or been carried away hundreds of years ago [...] there suddenly emerged from the black shade of the arch, a man' (211). It is significant that Quilp and his companion Tom Scott emerge from their niches on the half-hour, like automata marking the quarters in a clock. Dickens's description of the astronomical clock at Lyons Cathedral in Pictures from Italy recalls Quilp’s typical entrance:

A host of little doors flew open, and innumerable little figures staggered out of them, and jerked themselves back again, with that special unsteadiness of purpose, and hitching in the gait, which usually attaches to figures that are moved by clockwork. [...] There was [...] a small pigeon-hole, out of which another and a very ill-looking puppet made one of the most sudden plunges I ever saw accomplished: instantly flopping back again [...] banging his little door violently after him. ${ }^{67}$

The puppet (actually the Angel Gabriel) resembles Quilp in its awkward gait, violence and startling energy. Like the 'ill-looking puppet', Quilp springs from doorways and makes sudden plunges at his appalled audience: 'a little out-of-the-way door at the foot of the well staircase flew briskly open and a head popped out', and he disappears as quickly as he appeared: 'he darted in again with one jerk and clapped the little door to, like a figure in a Dutch clock when the hour strikes' (359-60).

Like an automaton, Quilp is repetitive, and as John Carey has pointed out, repetition is usually significant for Dickens: 'an effigy can be counted on to repeat its gesture each time it appears, just like a person, and it has the advantage of the strangeness and intensity that naturally adhere to something which only looks alive'. ${ }^{68}$ Quilp's repetitious hand-rubbing is indicative of a similar inauthenticity, hinting that he too might only look alive, as when 'he rubbed his hands slowly round, and round, and round again - with something fantastic even in his manner of performing this slight action' (30). His hands also suggest questionable humanity, being 'of a rough coarse grain', a description which could refer to metal, wood, or human skin (27). Quilp is small, as android automata often were, but his 'head and face were large enough for the body of a giant', linking him to the steelworkers who labour 'like giants' (27; 333). His expression rarely changes from a 'ghastly smile' that has 'no connection with any mirthful or complacent feeling' (27). This disconnected 'panting look' which 'had equally the effect of banishing all expression from his face, and rendering it, as far as it

Katherine Inglis, Becoming Automatous: Automata in The Old Curiosity Shop and Our Mutual Friend

19: Interdisciplinary Studies in the Long Nineteenth Century, 6 (2008) www.19.bbk.ac.uk 
afforded any index to his mood or meaning, a perfect blank', recalls the faintly sinister expression of the automaton, a copy of a human expression divorced from the experience of affect (361).

Quilp’s continual agitation and seemingly endless energy position him as the antithesis of Nell's static perfection. Though, like Gaskell's workers, his primce vice have evidently gone wrong, Quilp exploits his mechanical potential while Nell wilts, exploding from the page through vital excess. Automata continue to function long after the deaths of their creators and even after the devices seem broken, like Mrs Jarley's automaton nun. ${ }^{69}$ They endure in defiance of time and decrepitude, a quality Quilp, an elderly man with the strength, speed and energy of a much younger man, shares.

Quilp enjoys conditions that make other characters ill, subjecting his small frame to gustative ordeals that astonish his audience. His spectacular consumption of food, liquor and tobacco marks his otherness, anticipating the trope of twentieth-century science-fiction in which the android's mechanical nature is betrayed through a superhuman performance:

He ate hard eggs, shell and all, devoured gigantic prawns with heads and tails on, chewed tobacco and water-cresses at the same time and with extraordinary greediness, drank boiling tea without winking, bit his fork and spoon till they bent again, and in short performed so many horrifying and uncommon acts that the women were nearly frightened out of their wits, and began to doubt if he were really a human creature (45).

Quilp’s fondness for out-drinking and out-smoking lesser mortals surrounds him with a heated cloud of toxic smoke, which connects him with the 'tall chimneys' of the steel factories that stifle Nell with their 'plague of smoke' (338). His noxious exhalations choke Dick Swiveller, and he revels in atmospheres that 'must infallibly have smothered any other man' (168; 379). Quilp is a debased emblem of Victorian mechanical modernity, an amalgam of the factory automaton and the spectacular android, an ostentatious body of heat, smoke and combustion. Michael Hollington has observed that Quilp's 'supernatural wakefulness [...] parallels the Wolverhampton factories'. ${ }^{70}$ Quilp may not inhabit the industrial landscape or be engaged in industry (his career as a shipbreaker is unconvincing), but he expresses the corrupt spirit of the

\section{Katherine Inglis, Becoming Automatous: Automata in The Old Curiosity Shop and Our Mutual Friend}

19: Interdisciplinary Studies in the Long Nineteenth Century, 6 (2008) www.19.bbk.ac.uk 
novel's factory in his body. He combines the qualities of Mrs Jarley's automaton nun with those of the furnace to transcend the limits of the human; the nun is a dysfunctional but spectacular object that resists the passage of time, and the furnace pollutes in perpetuity (333).

However, Quilp’s perpetual motion is forcibly arrested by the destruction of his mechanism. Quilp is quenched, beaten (beyond repair), then toyed with in parodic anticipation of Nell's promised resurrection, becoming a pathetically lively corpse. The mutilated corpse is made to mimic the action of a living body, like an automaton:

The place, the deserted carcase had left so recently, a living man, was now a blazing ruin. There was something of the glare upon its face. The hair, stirred by the damp breeze, played in a kind of mockery of death - such a mockery, as the dead man himself would have revelled in when alive about its head, and its dress fluttered idly in the night wind (510).

This ghastly playfulness reveals the illusory quality of Quilp’s apparent freedom, transforming him into the ill-looking puppet that he always promised to be, the river's 'ugly plaything', a brutalised toy (510). This is the aspect of the automaton that Quilp's exuberant selfishness had obscured. Quilp, the aggressive self-mover, becomes a directed entity, a ludicrous corpse-puppet, twitching for the amusement of the spectator as the automaton-nun twitched for the amusement of the drunk barber. Perhaps Quilp was never as free as he appeared to be. Paul Schlicke acknowledges that Quilp's freedom, which he opposed to mechanical rigidity, is qualified by his self-destructive impulse toward isolation, a misuse of freedom that I would suggest is predetermined. ${ }^{71}$ Automata appear to be self-directed but are in fact predetermined by their design, unable to deviate from or exceed their parameters. They are puppets, marionettes, inauthentic agents. Quilp’s exploitation of his automatous qualities, though apparently liberating, in fact leads progressively to his isolation and the constriction of his freedom. His obsessive persecution of Kit Nubbles and his rejection of his wife could be interpreted as expressions of Quilp’s rejection of societal norms, but ultimately these free actions work against his interests, leading to the discovery of his crimes and a lonely death. Were Quilp truly free, he would have been able to deviate from his selfdestructive path and survive.

Katherine Inglis, Becoming Automatous: Automata in The Old Curiosity Shop and Our Mutual Friend

19: Interdisciplinary Studies in the Long Nineteenth Century, 6 (2008) www.19.bbk.ac.uk 
The mechanical element of Quilp’s hybridity overlaps with Henri Bergson's idea of the comic, predetermined human puppet, whose apparent freedom is an illusion. Bergson wrote that 'all that is serious in life comes from our freedom. [...] What, then, is requisite to transform all this into a comedy? Merely to fancy that our seeming freedom conceals the strings of a dancing-jack, - a marionette'. ${ }^{72}$ In life and especially in death, Quilp’s seeming freedom is an elaborate performance. He is fundamentally inauthentic, embracing a spectacular automatous existence that ultimately governs the manner of his death. Though Quilp's death and the treatment of his corpse are not comedic, the invocation of 'play' and 'mockery' reinforces the atypical lack of sympathy in the description of Quilp's death: there is not even a flicker of pity for Quilp, none of the sympathy shown for Rogue Riderhood's struggle for life, no equivalent insight into the desperation of a man facing oblivion to the portrayal of Fagin in jail. ${ }^{73}$ Instead, the narrator adopts Quilp’s disconnected, sadistic, almost psychopathic perspective, finding a bleak amusement in the mockery of death and treating a man's death with irreverence more appropriate to the destruction of a toy.

Quilp suffers the fate Nell fled from. He is stripped, with disturbing violence, of agency and voice, becoming an object in torment, a broken simulacrum of an autonomous being, a mute paralytic automaton. He dies frantic and isolated, struggling ineffectually against the current, prevented from calling to those who would rescue him if they could:

For all his struggling and plashing, he could understand [...] that they were all but looking on while he was drowned; that they were close at hand, but could not make an effort to save him; that he himself had shut and barred them out. He answered the shout - with a yell, which seemed to make the hundred fires that danced before his eyes tremble and flicker as if a gust of wind had stirred them. It was of no avail. The strong tide filled his throat, and bore him on, upon its rapid current. [...] One loud cry now - but the resistless water bore him down before he could give it utterance, and driving him under it, carried away a corpse (509-10).

It is the antithesis of Nell's death, which is perfect because Nell remains in control throughout: she is calm, articulate in sleep and delirium, and crucially is able to exert her agency even in her last moments, to kiss her friends and cling to her grandfather as

\section{Katherine Inglis, Becoming Automatous: Automata in The Old Curiosity Shop and Our Mutual Friend}

19: Interdisciplinary Studies in the Long Nineteenth Century, 6 (2008) www.19.bbk.ac.uk 
she dies (539). Unlike Quilp, whose inflexible malevolence leads inexorably to isolation and helplessness, Nell remains adaptable and in control. She is no puppet. Quilp’s death represents an extreme manifestation of that which Nell escaped from, but ultimately, his death also neutralises the threat of the automaton and its promise of dehumanisation. The smoke and heat that Quilp revelled in drive him to the water, perhaps the only force capable of overcoming this more-than-human figure. The automaton-nun, remember, was repaired. Only sheer weight of water ensures that Quilp will not be revived.

I am going to turn now to Our Mutual Friend, a novel which might seem to bear little resemblance to Dickens's 'sentimental' novel, but in which Dickens returns to the idea of the automaton as a symbol of the destabilization of personal agency. It expresses a more pessimistic attitude to human autonomy than the earlier novel. That which was contained by the quenching of Quilp in The Old Curiosity Shop is an immanent possibility in Our Mutual Friend, a more potent threat because it is not confined to a single individual or a discrete environment. Nell had something concrete to flee from in the shape of Quilp and the factory-town, but there is nowhere to run in Our Mutual Friend, as automatous beings seem to be everywhere. Echoes of Quilp reverberate through the text, as if the broken toy has been partially reanimated and redistributed: paralytic motions, staccato bursts of energy, the collapse of human agency and the danger of isolation figure prominently. Automata, mechanized suffering bodies, and the malevolence of the Thames towards the automaton play a crucial role in both novels. So too, perhaps, does Nell, reinterpreted for the less sentimental 1860s as the glorious, sharp, contrary visionary Jenny Wren, another child with an affinity for objects and a talent for combating automatism.

V

The Discreet Automaton in Our Mutual Friend

Michael Cotsell has described Our Mutual Friend as a novel in which 'if not everything is as alive as it seems, not everything is as dead'. ${ }^{74}$ The porous boundary between person and object in Mr Venus’s shop, where living beings become articulations and

Katherine Inglis, Becoming Automatous: Automata in The Old Curiosity Shop and Our Mutual Friend

19: Interdisciplinary Studies in the Long Nineteenth Century, 6 (2008) www.19.bbk.ac.uk 
objects seem perpetually to be on the verge of animating, extends beyond the taxidermist's walls to the world of the novel. The shop is a microcosm of the artificial, inauthentic existence that characterises 'Society', most evidently in the Veneering circle, which is in Albert D. Hutter's assessment characterised by 'mechanical functions and mechanical presences' ${ }^{75}$ It can be difficult to identify authentic subjects in this landscape of animate objects and de-animated beings, and it is possible for an automaton to pass as human and for a human to be mistaken for, or indeed to become, an automaton.

Venus also points towards the novel's remedy for this endemic automatism. As Hutter has observed, Venus, whose name connects him both to the goddess of love (who was also an animator) and the disarticulated Venus de Milo, fuses animation and articulation in his 'artful reconstitution of the human frame and the lifelike resurrection of all forms of animal life ${ }^{76}$ These mythic and material practices of reconstitution establish the paradigm for reanimation in the novel. The Pygmalion myth and automaton design meet in the figure of Jenny Wren, who acts as a mediator between the mythic and material drives. Jenny is a visionary, a seer of angels who is attuned to the mythic potential of the novel's apparently lifeless world, and she is also an adept practitioner of material reconstitution. Her world overlaps with Venus's. They share a client: the 'Doll' Jenny works for, who 'lost a canary bird', is presumably the owner of the stuffed canary Venus praises to the 'wicious' boy: 'There's animation! On a twig, making up his mind to hop!'(86; 224; 492).

Jenny, like Venus, is an accomplished reconstituent of the human frame, endowing formless wax with identity in her work as a doll's dressmaker. She seeks out original patterns in aristocratic ladies dressed for 'a Drawing Room, or a grand day in the Park, or a Show, or a Fête, or what you like. ${ }^{77}$ Costume imparts identity to otherwise undifferentiated waxwork, as it did in The Old Curiosity Shop, where a wig, shirt collar and male attire transform Mary Queen of Scots into a convincing Byron; for Jenny, giving Lady Belinda Whitrose's costume to a doll makes that doll 'Lady Belinda Whitrose' (431). Like Jarley, Jenny works principally with costume: there is no evidence that either character actually makes their waxworks. In Jenny's case, it is

Katherine Inglis, Becoming Automatous: Automata in The Old Curiosity Shop and Our Mutual Friend

19: Interdisciplinary Studies in the Long Nineteenth Century, 6 (2008) www.19.bbk.ac.uk 
probable that she would have bought her wax figures from a doll-maker; as an 1853 Household Words article on 'Dolls' explains, doll manufacture operated under a division-of-labour system, so that the typical English 'bonâ-fide wax doll', which consisted of several distinct parts, was 'the product of many minds and many hands'. ${ }^{78}$ A 'wax-doll' at this time would have been a composite figure with a wax head; cheap German-made 'wax-over' heads (papier-mâché dipped in wax) and more durable solid 'poured-wax' heads (made in England by the poured-wax method) could be purchased in Barbican; these heads were then attached to stuffed fabric or leather bodies, as were limbs made of wax or leather; finally, hair, glass eyes and the vitally important costumes were added. ${ }^{79}$ Great importance was placed on the costume of expensive dolls such as those Jenny distributes through the 'brilliantly-lighted' toy shop in Bond Street (430). As Household Words explains, dolls were expected to be adorned in the latest fashions, just as Jenny’s are:

Unquestionably there is a fashion in dolls and dolls' dresses, as in the attire of breathing mortals [...] There is one Paris house which prides itself almost exclusively on its dolls' dresses - not the dolls themselves, but the perfect fashion, and taste, and propriety of the dumb ladies' costume. ${ }^{80}$

These elegant figures were described in the Household Words article as 'composition' figures. ${ }^{81}$ Their beautiful attire conceals a hybrid form, a composite of distinct fragments. Venus also trades in composite figures composed of distinct fragments. The 'Beauty' he made for a school of art had 'one leg Belgian, one leg English, and the pickings of eight other people in it', while 'Miscellanies of several human specimens' comprise 'the lovely compo-one', a skeletal work-in-progress also known as the 'French gentleman’ (85; 489). Jenny and Venus’s occupations give them a privileged view of the human frame as a composite of fragments which can be decomposed and reconstituted, a perspective that proves advantageous in a novel populated with fragmented, degraded, and reanimated figures like Tippins, Wegg, Dolls, Riderhood, and Eugene. Jenny shares Venus's blurred perception of the distinction between animate and inanimate, speaking of her dolls as if they were human and of her human models and clients as if they were wax, just as Venus speaks of Silas Wegg's leg as though it were Wegg himself: Jenny remarks to Riah 'that's Lady Belinda hanging up

Katherine Inglis, Becoming Automatous: Automata in The Old Curiosity Shop and Our Mutual Friend

19: Interdisciplinary Studies in the Long Nineteenth Century, 6 (2008) www.19.bbk.ac.uk 
by the waist, much too near the gas-light for a wax one’ (431), as if the doll really were Lady Belinda, and Venus complains of Wegg's leg that 'I can't work you into a miscellaneous one, nohow. Do what I will, you can't be got to fit' (85). Jenny's sense of the animation in inanimate objects and the tragic human propensity to become objectlike is brought into focus by her alcoholic father's protracted de-animation, but ultimately enables her to play a crucial role as a mediator between the animate and inanimate worlds of the novel. Just as Venus mediates the satisfying resolution of the Boffin vs. Wegg plot, Jenny mediates the restoration of Eugene Wrayburn's constitution, thereby saving him from an automatous demise and from the materialistic, inauthentic existence of Veneering 'Society'.

Hutter notes the 'syntactical disruption' of the famous opening description of the Veneering circle, where 'all things' (humans and furniture) 'were in a state of high varnish and polish' (17). ${ }^{82}$ Syntactical indeterminacy also characterises the automaton's brief encounter with 'Society' at the Podsnaps' ghastly carpet dance. Mrs Podsnap goes to 'the music shop to bespeak a well-conducted automaton to come and play quadrilles for a carpet dance' (135). In keeping with the automaton's etymological and historical ambiguity, it is impossible to be sure what this ‘automaton' actually is. This could be a musical android or more probably, a mass-produced music box, as according to Christian Bailly nineteenth-century

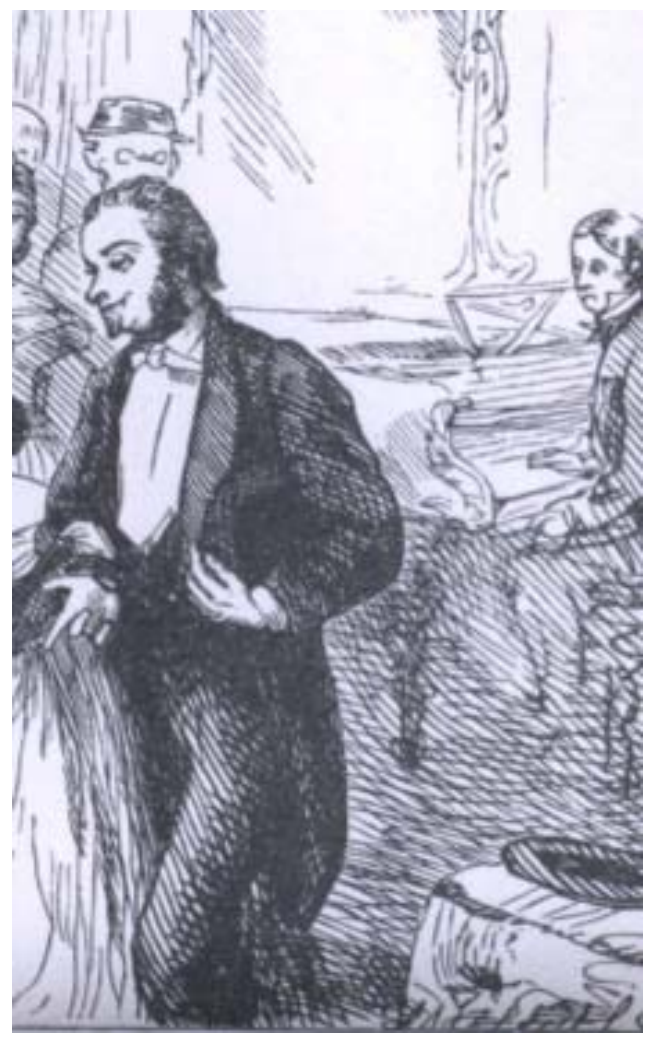

Fig. 2 Detail from 'Podsnappery' automata were 'associated as a matter of course with the music box' ${ }^{83}$ Any number of musical devices were available in the 1860s. Close scrutiny of Marcus Stone's illustration of 'Podsnappery' reveals the answer (see fig. 2); there is a small, dejected

Katherine Inglis, Becoming Automatous: Automata in The Old Curiosity Shop and Our Mutual Friend

19: Interdisciplinary Studies in the Long Nineteenth Century, 6 (2008) www.19.bbk.ac.uk 
sketchy figure in the corner gazing mournfully at the guests, who uniformly fail to notice him.

In the text, however, syntactic confusion is protracted so that the revelation of the automaton's humanity is withheld and he remains, at least potentially, a thing until Georgiana Podsnap, in a moment of panic at the approach of a dancing partner, refers to ‘the man at the piano’ (141). Prior to Georgiana’s indiscretion Dickens refers to him three times as 'the discreet automaton' $(138 ; 141)$. This protraction of uncertainty fits Ernst Jentsch's definition of the uncanny, which Freud rejected, in which the automaton is the exemplary uncanny object: ${ }^{84}$

In storytelling, one of the most reliable artistic devices for producing uncanny effects easily is to leave the reader in uncertainty as to whether he has a human person or rather an automaton before him in the case of a particular character. This is done in such a way that the uncertainty does not appear directly at the focal point of his attention. ${ }^{85}$

The discreet automaton's secret is, as Jentsch's formula specifies, never the focal point of the chapter. He remains barely visible and marginal in the gathering, both in the illustration and the text. Dickens's deferral of certainty is therefore potentially uncanny not only because the reader cannot be sure of the musician's humanity, but also because whether the musician is human or not doesn't seem to matter as long as he/it fulfils his/its function. The musician is effectively a commodity. He has been purchased at the music shop just as an automaton would have been purchased, and is fixed in a single position just as an automaton is fixed to a box within which its mechanism is concealed. Constraint characterises Dickens's musician, who like even the most sophisticated automata-musicians, can only perform the sequence he has been hired/programmed to play:

The discreet automaton had got behind the bars of the piano music-desk, and there presented the appearance of a captive languishing in a rosewood jail (138).

And then the captive at the piano played another 'set', expressive of his mournful aspirations after freedom (143).

Trapped behind the piano, the musician is compelled to perform Mrs Podsnap's 'blossomless tuneless "set”' just as an automaton musician would have followed a set

Katherine Inglis, Becoming Automatous: Automata in The Old Curiosity Shop and Our Mutual Friend

19: Interdisciplinary Studies in the Long Nineteenth Century, 6 (2008) www.19.bbk.ac.uk 
sequence (141). The epithet of 'discreet automaton' thus remains appropriate even after Georgiana's revelation. There is nothing to distinguish the glum pianist from a machine. Perhaps more disturbingly, no-one notices his condition. In the Veneering circle to be automatous is neither aberrant nor noteworthy; Podsnap's affectless, reactive pronouncements typify this automatous Society, where platitudes ('We Englishmen are Very Proud of our Constitution, Sir') and random interjections ('ESKER') pass for conversation (136-37). Thus the musician's unstable condition casts doubt on the whole company; can the reader determine whether any of these mechanical figures are humans or automata?

VI

\section{Reconstitution}

It is significant that Our Mutual Friend's automaton should be a musician. His occupation points to a psychological aspect of the indeterminacy between animate and inanimate that becomes overt in the latter stages of the novel, where automatic mental processes threaten to overwhelm dangerously insubstantial human consciousnesses and negate personal autonomy. Automatism is defined as 'a state in which the individual performs simple or complex actions [...] without having full awareness of what he is doing'. ${ }^{86}$ This includes normal (as opposed to pathological) automatism, usually exemplified by a musician, whose skill is acquired through practice; thus 'the more expert the performer is, the greater will be the degree of automatism displayed'. ${ }^{87}$ An early instance of this is David Hartley's description in Observations on Man (1749) of a harpsichord player's performance in terms of a 'secondarily automatic' movement, a conditioned reflex developed through practice. It is perhaps significant that Hartley developed this idea in the 1740s, the decade that Vaucanson's musicians made their European tour. For Hartley's accomplished harpsichord player, like Vaucanson's androids, play is an automatic, mechanical action, conducted without the intervention of will and even without agency; as Richard C. Allen explains, 'one sits down at the piano, and the music plays' ${ }^{88}$

Katherine Inglis, Becoming Automatous: Automata in The Old Curiosity Shop and Our Mutual Friend

19: Interdisciplinary Studies in the Long Nineteenth Century, 6 (2008) www.19.bbk.ac.uk 
The design of Vaucanson's android musicians depended upon a process of decomposition and reconstitution, a form of reverse engineering in which the automaton's designer broke down a complex human skill into a series of unique movements, which were then replicated and recombined in the automaton's mechanism. Vaucanson made this process of deconstruction and reconstitution explicit in his report for the Académie des Sciences (translated into English in 1742) on the mechanism of his German flute-player. The first part of the account is an anatomical description of a flautist, explaining 'how the Wind is modified, and what are the Parts in a living Person which contribute to give it more or less Force' ${ }^{89}$ Vaucanson describes, in exhaustive detail, how a flautist produces and modulates sound, tracing the progress of air from the pectoral muscles to the lungs, wind-pipe, lips and flute. Dissection is followed by mechanical reconstruction in the second part of the account, a correspondingly detailed description of how each element of the mechanism contributes to the conduction and modification of air. Through decomposition and reconstruction Vaucanson reveals the complexity of a performance that appears fluid and effortless, so that for example to produce a single ' $D$-note below' requires four separate mechanical adjustments. ${ }^{90}$

The automaton designer's methodology reappears in mid-nineteenth-century psychological and physiological discussions of acquired automatic action. These accounts, which break down complex skills into sequences of unique movements, invariably use piano-play as an example of acquired automatic action, perhaps in homage to Hartley's automatous harpsichord player. ${ }^{91}$ For Johannes Müller 'the pianoforte player' is 'an example [...] of the faculty of insulation of the nervous influence in its highest perfection', by which Müller referred to the acquired ability to overcome 'associate or consensual' (involuntary) movements through practice. ${ }^{92} \mathrm{He}$ wrote that 'the more frequently certain groups of fibres are excited to action by the influence of the will, the more capable do they become of isolated action; this is exemplified in performers on the piano-forte, \&c'. ${ }^{93}$ In psychology, Herbert Spencer also used the pianist to explain how memory becomes 'by constant repetition, automatic', and thereby 'ceases to be part of Memory'. ${ }^{94}$ For Spencer, the pianist displayed 'the most marked instance of the gradual lapse of memory into automatic

Katherine Inglis, Becoming Automatous: Automata in The Old Curiosity Shop and Our Mutual Friend

19: Interdisciplinary Studies in the Long Nineteenth Century, 6 (2008) www.19.bbk.ac.uk 
coherence'. ${ }^{95}$ His explanation recalls Vaucanson's Account, breaking the process down into a series of unique 'psychical changes' then reconstituting the sequence through the unifying principle of automatism, so that 'by long continued practice [...] the series of psychical changes that occur between seeing the mark and striking the appropriate key, have coalesced into one almost automatic change'. ${ }^{96}$ This acquired automatism, Spencer concludes, explains how a pianist can play competently whilst holding a conversation: the skilled musician plays automatically and almost unconsciously.

Both Spencer and Müller’s accomplished pianists are effectively unconscious of the action of playing. Müller's pianist, having trained his nerves and muscles through practice, has forgotten that he is now suppressing the associated involuntary movements that originally marred his play. Spencer's pianist is barely conscious of his actions. The accomplished musician thus operates in a state approaching automatism, having learned to separate mechanical muscular action from the distraction of consciousness. Like Hartley's musician, he sits down and the music plays.

However, automatism is not normative in Our Mutual Friend. The automatism that enhances Müller and Spencer's pianists serves to denigrate the musician in the novel. The 'discreet automaton' is in a precarious position: threatened with redundancy by mass-produced musical doppelgängers, possibly mechanical himself, possibly unconscious (and no-one would notice if he were), he is at risk of becoming truly automatous. The consequences of such a transformation are uniformly dire in Our Mutual Friend, as Stone's illustration indicates. In 'Podsnappery' the musician is literally fading into the background and melting into his piano. It is difficult to discern where his hands end and his piano begins, as if he is not distinct from the instrument. He is starting to disappear.

\section{VII}

\section{Paralytic Animation}

The automaton reaches its nadir in the ‘winding-up’ of Mr Dolls, whose ‘very breathing [...] was contemptible, as it laboured and rattled in that operation, like a blundering

Katherine Inglis, Becoming Automatous: Automata in The Old Curiosity Shop and Our Mutual Friend

19: Interdisciplinary Studies in the Long Nineteenth Century, 6 (2008) www.19.bbk.ac.uk 
clock' (241). The key to Dolls's mechanism is alcohol, which negates his personal autonomy and reduces him to an organic automaton. Eugene (who named Jenny Wren's father 'Mr Dolls') exploits his automatous nature, feeding him rum, which he describes as ‘winding up Mr Dolls’: “ “It will be necessary, I think,” he observed, “to wind up Mr. Dolls, before anything to any mortal purpose can be got out of him. Brandy, Mr. Dolls, or -?” ' (527). Dolls can only respond, with the mechanical predictability of an automaton, 'Threepenn'orth Rum' (528). When he collapses, he is said to be 'runningdown’ (528).

Gripped by 'the trembles’ (delirium tremens) Dolls’s mechanical body seems to have a mind of its own. Freud's observations on the uncanny quality of an autonomous body fragment speak to Mr Dolls’s condition:

Dismembered limbs, a severed head, a hand cut off at the wrist [...] feet which dance by themselves [...] - all these have something peculiarly uncanny about them, especially when, as in the last instance, they prove capable of independent activity in addition. ${ }^{97}$

Dispossessed of his will, Dolls's body parts act as uncanny fragments, capable of independent action. His disconnected and incoherent utterances express his internal disintegration, as does his autonomous hand, which flings away the money Eugene hands him (613). Sussman and Joseph have discussed instances of such fragmentation and loss of control in relation to Dickens's 'cyborgian anxiety':

In Dickens's imagination, too, parts or sub-systems of the body break from central subjective control; organs behave as autonomous beings. Along with the reciprocity of the animate and the inanimate, a central quality of Dickens's imagination lies in parts of the body acting independently. Throughout Dickens mechanical parts or systems of the body strike out for themselves, become, in Victorian terms, self-acting machines. ${ }^{98}$

For Sussman and Joseph, teeth are particularly redolent of this cyborgian anxiety, being of the body, yet apparently inorganic and easily replaceable. Though writing on Dombey and Son, their observations are salient to Dolls's situation, for his teeth have a life of their own:

Teeth occupy the boundary in the body between the firm and the hard and the wet and the organic [...] they thus appeal to Dickens's imagination of the slipperiness of that boundary [...] They seem to participate more in the

Katherine Inglis, Becoming Automatous: Automata in The Old Curiosity Shop and Our Mutual Friend

19: Interdisciplinary Studies in the Long Nineteenth Century, 6 (2008) www.19.bbk.ac.uk 
'firmness' of machinery, of the wooden looms and locomotives, of the body as machine rather than organic being. They thus easily figure the sense of the body as composed of inanimate parts that are imbued with animation and volition, not to mention phallic aggression, once the body is imagined as automaton or engine. ${ }^{99}$

Teeth are equally slippery and aggressive customers in Our Mutual Friend, possessed of independent animation and an apparent wish to make mischief. Dolls cannot control his teeth: " "Ugh, you disgraceful boy!” exclaimed Miss Wren, attracted by the sound of his chattering teeth, "I wish they'd all drop down your throat and play at dice in your stomach!” ' (522). Dolls's autonomous teeth recall an instance of animation in Venus's shop, the centre of the novel's confusion of animate and inanimate. Venus is plagued by wandering teeth, which seem to be able to move independently. When one slips into an errand-boy's change Venus comments mournfully that 'they drop into everything. There was two in the coffee-pot at breakfast time. Molars' (86).

Venus's errant teeth are obviously comic rather than uncanny objects, but Dolls's autonomous teeth are genuinely unsettling in betraying his degradation. They anticipate his terrible fate, which is to be reduced to the condition of Venus's articulations, an inanimate object which was once a living being. Mr Dolls's fellowship with the pickled articulations is made clear by Jenny's complaint that such a bad child is 'fit for nothing but to be preserved in the liquor that destroys him, and put in a great glass bottle as a sight for other swipey children of his own pattern' (523). It is also significant that Dickens describes him as a 'paralytic scarecrow': his spasmodic, convulsive movements recall the fitful, eccentric animation of Venus's articulations, which Dickens characterised as paralytic animation (696):

Mr. Wegg, looking back over his shoulder as he pulls the door open by the strap, notices that the movement so shakes that crazy shop, and so shakes a momentary flare out of the candle, as that the babies - Hindoo, African, and British - the 'human warious,' the French gentleman, the green glass-eyed cats, the dogs, the ducks, and all the rest of the collection, show for an instance as if paralytically animated; while even poor Cock Robin at Mr. Venus's elbow turns over on his innocent side (91).

Paralytic articulations, The Old Curiosity Shop's paralytic nun, a convulsive mechanical man; these liminal dysfunctional figures point to a connection in Dickens’s imagination

\section{Katherine Inglis, Becoming Automatous: Automata in The Old Curiosity Shop and Our Mutual Friend}

19: Interdisciplinary Studies in the Long Nineteenth Century, 6 (2008) www.19.bbk.ac.uk 
between pathognomonic movements and animated objects. This connection is most explicit in Dolls's death scene, where Dolls's mechanized body gains control. Dolls disappears, absorbed by a machine, much as the discreet automaton was shown melting away in Stone’s 'Podsnappery':

Force of police arriving, he recognized in them the conspirators, and laid about him hoarsely, fiercely, staringly, convulsively, foamingly. A humble machine, familiar to the conspirators and called by the expressive name of Stretcher, being unavoidably sent for, he was rendered a harmless bundle of torn rags by being strapped down upon it, with voice and consciousness gone out of him, and life fast going (711).

Dolls's excessive emotion (hoarsely, fiercely) becomes excessive movement (convulsively, foamingly), marking a shift from affect to spasm, conscious to unconscious, subject to mere object, until Dolls is conflated with the 'humble machine' to which he has been strapped, becoming 'this machine' (711), then merely 'it' (712). The automatous being, having lost all autonomy and animation, becomes like Quilp, a broken toy: 'there, in the midst of the dolls with no speculation in their eyes, lay Mr. Dolls with no speculation in his' (712). It does seem that in Dickens's imagination, the automaton is inevitably doomed to destruction; even in an early comic piece on a proposal for an automaton police force inspired by a suggestion by George Cruikshank for an illustration, the automata are designed to be destroyed by drunken noblemen. ${ }^{100}$ Quilp, Dolls, and the automaton police are predestined to become shattered toys, violently broken into fragments and deprived of animation in an unsettling form of 'amusement'.

VIII

\section{Venus Intercedes}

Dolls's fate is intimately connected to Eugene Wrayburn's: Dolls's decline was precipitated by Eugene's ruthless exploitation of his alcoholism, Eugene's ordeal occurs immediately after Dolls's funeral, and the ordeal is modelled on Dolls's death-agony. Immobile and incoherent, Eugene becomes Dolls, uncanny and automatous, losing his

Katherine Inglis, Becoming Automatous: Automata in The Old Curiosity Shop and Our Mutual Friend

19: Interdisciplinary Studies in the Long Nineteenth Century, 6 (2008) www.19.bbk.ac.uk 
mind while his body acquires a mind of its own. His eyes acquire the 'unmeaning stare' familiar from the recent laying out, and he oscillates between feeble consciousness and delirium, believing that he is 'wandering', as Dolls did in his last hours (729; 719). Crucially, he displays the mechanical repetitiveness shared by both Quilp and Dolls:

The one word, Lizzie, he muttered millions of times. In a certain phase of his distressful state, which was the worst to those who tended him, he would roll his head upon the pillow, incessantly repeating the name in a hurried and impatient manner, with the misery of a disturbed mind, and the monotony of a machine. Equally, when he lay still and staring, he would repeat it for hours without cessation, but then, always in a tone of subdued warning and horror (720-21).

Eugene becomes an organic speaking-machine, compelled to repeat a single word, his speech stripped of context and intonation. This is a terrible form of parody, a mechanical simulation of consciousness and affect. Eugene becomes an automatous mockery of a suffering lover.

A single utterance of the word 'wife' interrupts the litany of 'Lizzies' and reverses Eugene's decline. 'Wife' possesses a similar transformative power in the Pygmalion myth, where Pygmalion's incompletely uttered prayer for the ivory maid to become his wife is interpreted and granted by Venus.

'If you gods can give all things, may I have as my wife, I pray' - he did not dare to say: 'the ivory maiden,' but finished: 'one like the ivory maid.' However, golden Venus, present at her festival in person, understood what his prayers meant. ${ }^{101}$

The Pygmalion myth pervades Our Mutual Friend: Bradley Headstone aspires to be a pedagogical Pygmalion to Lizzie’s ivory maid, the Boffins undertake their own version of Pygmalion's project in their moral re-education of Bella, and Jenny manhandles her wax dolls as if they were alive, like a sadistic Pygmalion. Both Venuses (goddess and taxidermist) are great animators, and significantly, as in the myth, it is not Pygmalion who brings the statue to life in the novel.

In his automatous state, Eugene occupies the position of the ivory maid. His injuries keep him motionless, his relapses into insensibility render him mindless as a statue, his lover longs for him to come to life. Yet he is still Pygmalion, longing for marriage but unable to say so. Jenny acts as a translator for Eugene, detecting (as the

Katherine Inglis, Becoming Automatous: Automata in The Old Curiosity Shop and Our Mutual Friend

19: Interdisciplinary Studies in the Long Nineteenth Century, 6 (2008) www.19.bbk.ac.uk 
goddess did) the unspoken phrase, the 'leading word' that saves him (722). Only Jenny or Mr Venus could have translated for Eugene in his automatous state and enabled his recovery. Like Mr Venus, Jenny can see the potential for animation in inanimate objects and de-animated humans. As witness to her father's degradation, she is familiar with the mechanistic speech of the human automaton; as witness to Rogue Riderhood's restoration from drowning, she is also aware that exanimated humans can be reanimated. She mediates for Eugene just as she spoke for her dolls and interpreted her father's inchoate utterances, acting as 'an interpreter between this sentient world and the insensible man', saving him from Quilp’s doom (720). Quilp was dragged beneath the water in a desperate attempt to communicate; Eugene's 'unspeakable yearning to have speech' has the same effect, shortening his periods of coherence: '[a]s the man rising from the deep would disappear the sooner for fighting with the water, so he in his desperate struggle went down again’ (721). Through Jenny, the unspeakable utterance 'wife’ infuses life into Eugene, just as Pygmalion's unspoken prayer 'wife' animated the ivory maid. The reanimated Eugene is insistently organic, as if to stress the destruction of his machine-element. The passing of the mechanical pathology is signalled through repeated references to Eugene's 'blood', 'glow' and 'animation', in explicit contrast to the 'slight coldness' of Society (791).

IX

\section{The Imaginary Automaton}

Though Eugene escapes the terrible fate of Mr Dolls, the automaton is not contained at the end of Our Mutual Friend as it was in The Old Curiosity Shop through Nell's escape and Quilp’s humiliation. The Voice of Society remains automatous and Eugene is aware that he could slip back into his old habits. That which in The Old Curiosity Shop was dangerously attractive but ultimately illusory is an immanent reality in the later novel; anyone can become automatous and that which Venus can impart, he can as easily take away. He warns the aggressive errand boy ‘you've no idea how small you'd come out, if I had the articulating of you' (86) and threatens Wegg: 'I like my art, and I know how

Katherine Inglis, Becoming Automatous: Automata in The Old Curiosity Shop and Our Mutual Friend

19: Interdisciplinary Studies in the Long Nineteenth Century, 6 (2008) www.19.bbk.ac.uk 
to exercise my art' (489). It is easy to be to be stripped of one's will and become an organic machine; it can be effected by three-penn'orth rum, a blow to the head, or a musician's wage. The consequences of the transformation are uniformly abject: the novel's automatous beings are pathetic, inflexible, isolated, and, like Quilp at his death, unable to communicate; Podsnap cannot empathise, Mr Dolls dies alone in the middle of a crowd, ignorant of Jenny's love, and Eugene's automatous state is characterised by his inability to speak coherently. It takes a miraculous intervention to save Eugene from Quilp's doom; in The Old Curiosity Shop the terrible malignity of the automaton was quenched by the Thames, but in Our Mutual Friend the automaton is dragged from the water and raised to humanity through the intercession of an unlikely acolyte of Venus.

The automaton's presence in such different novels, written decades apart, is a marker both of its significance in Dickens's imagination and its continued currency in popular culture and the Victorian material imagination. The imaginary automaton was not unique to Enlightenment philosophy, proving to be just as troublesome and disruptive a figure in nineteenth-century debates on the nature of freedom, workplace practices, industrial configurations, and the relationship between the mind and body. Dickens's automata and automatous beings draw on these associations and the miscellaneous careers of the actual automata that were presented for contemplation in shows, drawing-rooms, nurseries and shops. His automata are both concrete and imaginary, palpable and metaphoric, evident and enigmatic. Above all, they cast doubt on the supposedly authentic beings they mimic. In Dickens's material imagination, to display an automatous affinity is to be diminished.

\section{List of Illustrations}

Figure 1: 'Euphonia’, The Illustrated London News, 8 August 1846.

Figure 2: Detail from Marcus Stone, 'Podsnappery’, illustration for Our Mutual Friend.

\section{Endnotes:}


${ }^{1}$ Chambers Encyclopaedia (London: W. \& R. Chambers, 1860) I, pp. 577-78 (p. 577). London, Senate House Library, Harry Price Collection.

2 Steven Connor, Dumbstruck: A Cultural History of Ventriloquism (Oxford: Oxford University Press, 2000), p. 340.

${ }^{3}$ Connor, pp. 340-41.

${ }^{4}$ See Linda M. Strauss, 'Reflections in a Mechanical Mirror: Automata as Doubles and as Tools', Knowledge and Society: Research in Science and Technology Studies: Material Culture, 10 (1996), 179207, and Otto Mayr, Authority, Liberty and Automatic Machinery in Early Modern Europe (Baltimore and London: The Johns Hopkins University Press, 1986).

${ }^{5}$ Herbert Sussman and Gerhard Joseph, 'Prefiguring the Posthuman: Dickens and Prosthesis', Victorian Literature and Culture, (2004), 617-628 (p. 617).

${ }^{6}$.Sussman and Joseph, p. 617.

${ }^{7}$ Sussman and Joseph, p. 620. However, Sussman and Joseph do go on to contrast Dickens's liberal, selfacting prosthetic subjects with a 'cyborgian anxiety' that the body may gain control of the subject, which is closely related to the automata anxiety I discuss in this essay. See Sussman and Joseph pp. 622-26.

${ }^{8}$ Richard D. Altick, The Shows of London (Cambridge, MA and London: Belknap, 1978), p. 65; Annie Amartin-Serin, La Création Défiée: L'Homme Fabriqué dans la Littérature (Paris: Presses Universitaires de France, 1996), p. 26; Jacques Vaucanson, Account of the Mechanism of an Automaton, or Image Playing on the German-Flute: As it was presented in a Memoire, to the Gentlemen of the Royal Academy of Sciences at Paris, trans. by J. T. Desaguliers (London: T. Parker, 1742), p. 23; Gaby Wood, Living Dolls: A Magical History of the Quest for Mechanical Life (London: Faber and Faber, 2002), p. 23.

${ }^{9}$ Altick, p. 66.

${ }^{10}$ Constance King, Metal Toys and Automata (London: The Apple Press, 1989), p. 19.

11 Excerpt from Les Androides Jaquet-Droz. Dir. Philippe Sayous. TIL Productions. 2001. $<$ Hhttp://www.automates-

anciens.com/video_1/female_musician_automaton_android_jaquet_droz_500.wmvH $>\quad$ [accessed 8 October 2007]. The Musicienne is now on display at the Musée d'Art et d'Histoire at Neuchâtel.

${ }^{12}$ John McCormick, The Victorian Marionette Theatre (Iowa City: University of Iowa Press, 2004), pp. 12-15; Altick, pp. 335-38.

${ }^{13}$ Henry Mayhew, London Labour and the London Poor, 4 vols (New York: Dover, 1968) [1861-62] I, p. 4; III, pp. 77-79.

${ }^{14}$ Connor, p. 336.

${ }^{15}$ Connor, p. 340. See Thomas L. Hankins and Robert J. Silverman, Instruments and the Imagination (Princeton, NJ: Princeton University Press, 1995), chapter 8, for a fascinating analysis of attempts by

\section{Katherine Inglis, Becoming Automatous: Automata in The Old Curiosity Shop and Our Mutual Friend}

19: Interdisciplinary Studies in the Long Nineteenth Century, 6 (2008) www.19.bbk.ac.uk 
natural magicians, physiologists, acousticians, inventors and musicians to imitate the human voice mechanically from the eighteenth-century to the advent of the telephone.

${ }^{16}$ James W. Cook, Jr, 'From the Age of Reason to the Age of Barnum: The Great Automaton ChessPlayer and the Emergence of Victorian Cultural Illusionism', Winterthur Portfolio: A Journal of American Material Culture, 30:4 (1995), 231-57 (p. 245); Antonia Fraser, A History of Toys (London: Weidenfeld and Nicolson, 1966), p. 120; Hankins and Silverman, p. 213.

${ }^{17}$ Alfred Chapuis and Edmund Droz, Automata: A Historical and Technological Study, trans. Alec Reid (Neuchâtel: Editions du Griffon, 1958), p. 323; Hankins and Silverman, pp. 191-96. For more on the Turk (Kempelen's 'bagatelle') see Cook, 'From the Age of Reason to the Age of Barnum'; Simon Schaffer, 'Babbage's Dancer and the Impresarios of Mechanism', in Cultural Babbage: Technology, Time and Invention, ed. by Francis Spufford and Jenny Uglow (London: Faber and Faber, 1996), pp. 52-80; Tom Standage, The Mechanical Turk: The True Story of the Chess-Playing Machine That Fooled the World (London: Allen Lane, 2002).

18 'Talking Machines', All the Year Round, 24 September 1870, pp. 393-96 (p. 396)

${ }^{19}$ Hankins and Silverman, pp. 218-19; David Lindsay, Madness in the Making: The Triumphant Rise and Untimely Fall of America's Show Inventors (New York: Kodansha International, 1997), pp. 168-69; Standage, p. 80.

${ }^{20}$ Altick, p. 353; Chapuis and Droz, p. 323; Hankins and Silverman, p. 216.

${ }^{21}$ Hankins and Silverman, p. 219.

${ }^{22}$ Chapuis and Droz, pp. 323-24. Altick’s description differs slightly, listing the components as bellows, a rubber tube corresponding to the trachea, an ivory reed with rubber ligaments corresponding to the larynx, and an articulated lower jaw; Altick, p. 354.

${ }^{23}$ Altick, p. 354.

24 'The Euphonia, or Speaking Automaton', The Illustrated London News, 25 July 1846, p. 59.

${ }^{25}$ Altick, p. 354.

${ }^{26}$ Christian Bailly, Automata: The Golden Age 1848-1914 (London: Sotheby’s, 1987), pp. 14-15.

${ }^{27}$ Fraser, p. 118.

${ }^{28}$ King, pp. 124-25.

${ }^{29}$ Fraser, p. 118.

${ }^{30}$ Bailly, p. 217.

${ }^{31}$ Bailly, pp. 217-21.

${ }^{32}$ See Silvio A. Bedini, 'The Role of Automata in the History of Technology', Technology and Culture, 1 (1964), 24-42; Derek J. De Solla Price, 'Automata and the Origins of Mechanism and Mechanistic Philosophy', Technology and Culture, 1 (1964), 9-23. Sir David Brewster's argument that eighteenthcentury automaton design had led, however indirectly, to the innovations of the industrial revolution was

Katherine Inglis, Becoming Automatous: Automata in The Old Curiosity Shop and Our Mutual Friend

19: Interdisciplinary Studies in the Long Nineteenth Century, 6 (2008) www.19.bbk.ac.uk 
restated in encyclopaedias and articles on automata throughout the nineteenth-century: Sir David Brewster, Letters on Natural Magic, Addressed to Sir Walter Scott, Bart (London: John Murray, 1833), p. 286.

${ }^{33}$ Hal Foster, Compulsive Beauty (Cambridge MA and London: MIT Press, 1993), p. 131. See also Simon Schaffer, 'Enlightened Automata', in The Sciences in Enlightened Europe, ed. by William Clark, Jan Golinski and Simon Schaffer (Chicago and London: University of Chicago Press, 1999), pp. 126-65 (p. 144) for a summary of Vaucanson's career in the 1740s.

${ }^{34}$ Foster, p. 131.

${ }^{35}$ See Norris Pope on Dickens's 'sentimental politics' in The Old Curiosity Shop and its machinery question context: Norris Pope, 'The Old Curiosity Shop and the New: Dickens and the Age of Machinery', Dickens Quarterly 13:1 (1996), 3-18. For more on Dickens's interest in factory legislation, see Sally Ledger, Dickens and the Popular Radical Imagination (Cambridge: Cambridge University Press, 2007), pp. 187-91; K. J. Fielding and Anne Smith, 'Hard Times and the Factory Controversy: Dickens vs. Harriet Martineau’, Nineteenth-Century Fiction, 24:4 (1970), 404-27.

${ }^{36}$ See Sally Ledger on machinery in Little Dorrit and Steve Connor on metallurgy in Great Expectations: Ledger, Dickens, p. 224; Steve Connor, 'Forgeries: The Metallurgy of Great Expectations', talk given at Dickens Day, Birkbeck, University of London, 24 September 2005 $<$ Hhttp://www.bbk.ac.uk/english/skc/forgeries/forgeries.pdf $>$ H [accessed 1 October 2005].

${ }^{37}$ Tamara Ketabgian, 'The Human Prosthesis: Workers and Machines in the Victorian Industrial Scene', Critical Matrix: The Princeton Journal of Women, Gender, and Culture, 11:1 (1997), 4-32 (pp. 5-6).

${ }^{38}$ Ketabgian, p. 9; p. 13. See pp. 8-17 for a lucid discussion of Marx's negotiation of subjectivity, particularly in Capital.

${ }^{39}$ Maxine Berg, The Machinery Question and the Making of Political Economy 1815-1848 (Cambridge: Cambridge University Press, 1980), p. 181. See Simon Schaffer, 'Babbage's Intelligence' in The Hypermedia Research Centre, for an overview of literature on the factory system in the 1830s and 1840s $<$ Hhttp://www.hrc.wmin.ac.uk/theory-babbagesintelligence-print.htmlH $>$ [accessed 14th June 2007]. See Andrew Zimmerman, 'The Ideology of the Machine and the Spirit of the Factory: Remarx on Babbage and Ure', Cultural Critique, 37 (1997), 5-29, for a Marxist analysis of Charles Babbage and Andrew Ure's mechanical ontology.

${ }^{40}$ Andrew Ure, The Philosophy of Manufactures: Or, an Exposition of the Scientific, Moral, and Commercial Economy of the Factory System (London: Charles Knight, 1835), pp. 13-14.

${ }^{41}$ Berg, p. 199. See Nicola Bown on Ure's magical rhetoric, the miniaturisation of the fairy-like worker and the representation of the factory as a giant: Nicola Bown, Fairies in Nineteenth-Century Art and Literature (Cambridge: Cambridge University Press, 2001), pp. 64-65, p. 90.

${ }^{42}$ Ure, p. 20.

Katherine Inglis, Becoming Automatous: Automata in The Old Curiosity Shop and Our Mutual Friend

19: Interdisciplinary Studies in the Long Nineteenth Century, 6 (2008) www.19.bbk.ac.uk 
${ }^{43}$ Ure, p. 15.

44 Peter Gaskell, Artisans and Machinery: The Moral and Physical Condition of the Manufacturing Population Considered with Reference to Mechanical Substitutes for Human Labour (London: John W. Parker, 1836), p. 5; p.7.

${ }^{45}$ Gaskell, pp. 143-44.

${ }^{46}$ Bibliotheca Classica: Or, a Classical Dictionary; Containing a Copious Account of the Principal Proper Names Mentioned in Ancient Authors; With the Values of Coins, Weights, and Measures, Used Among the Greeks and Romans; and a Chronological Table, ed. by J. Lempriere, rev. by Charles Anthon, 2 vols (New York: G \& C \& H. Carvill, H.C. Sleight, 1833), I, pp. 284-5.

${ }^{47}$ Ure, p. 16.

${ }^{48}$ Marx, p. 425.

${ }^{49}$ Gaskell, p. 231.

${ }^{50}$ Gaskell, p. 144.

${ }^{51}$ Gaskell, p. 153.

52 Gaskell, p. 184.

${ }^{53}$ Gaskell, pp. 188-89.

${ }^{54}$ Charles Dickens, The Old Curiosity Shop (1840-41), ed. by Elizabeth M. Brennan (Oxford: Oxford University Press, 1998), p. 239. Further references will be given in the text.

${ }^{55}$ Ure, p. 15.

${ }^{56}$ Charles Dickens, 'The Amusements of the People (I)', in Dickens' Journalism Volume 2: 'The Amusements of the People' and Other Papers: Reports, Essays and Reviews 1834-51, ed. by Michael Slater (London: Dent, 1996), pp. 179-85 (pp. 180-81), first published in Household Words, 30 March 1850.

${ }^{57}$ Dickens, 'The Amusements of the People (I)', p. 181.

${ }^{58}$ M. Norton Wise, 'The Gender of Automata in Victorian Britain', in Genesis Redux: Essays in the History and Philosophy of Artificial Life, ed. by Jessica Riskin (Chicago and London: University of Chicago Press, 2007), 163-95 (p. 191).

${ }^{59}$ Wise, p. 169; p. 171.

${ }^{60}$ I am thinking specifically of Deirdre Coleman's discussion of the performance of gender by the Musicienne and Babbage's dancer in her talk on the Minds, Bodies, Machines project at the Disciplines of Feeling workshop, held at Birkbeck, University of London, on 5 July 2007. For more responses to the perceived 'femininity' of nineteenth-century automata see Simon Schaffer on the relationship between materialist philosophy, automata shows, and women's medicine, Jay Clayton on the 'whiff of eroticism' in Babbage's presentation of his 'Silver Lady', and Ib Johansen on the nineteenth-century association between automata, femininity and the sublime: Schaffer, 'Babbage’s Dancer’, p. 56; Jay Clayton, Charles

Katherine Inglis, Becoming Automatous: Automata in The Old Curiosity Shop and Our Mutual Friend

19: Interdisciplinary Studies in the Long Nineteenth Century, 6 (2008) www.19.bbk.ac.uk 
Dickens in Cyberspace: The Afterlife of the Nineteenth Century in Postmodern Culture (Oxford and New York: Oxford University Press, 2003), p. 106; Ib Johansen, 'The Monster and the Automaton: Variations on the Grotesque and the Sublime in Science Fiction', Dolphin, 17 (1989), 101-21. Donna J. Haraway, Simians, Cyborgs, and Women: The Reinvention of Nature (London: Free Association, 1991).

${ }^{61}$ See Adelheid Voskuhl, 'Motions and Passions: Music-Playing Women Automata and the Culture of Affect in Late Eighteenth-Century Germany', in Genesis Redux, pp. 293-320, for an analysis of affective responses to female automata-musicians and the mechanistic tone of pedagogical music texts which sought to train pianists to control their own and their audiences' emotions.

${ }^{62}$ Ure, pp. 22-23.

63 John Carey, The Violent Effigy: A Study of Dickens' Imagination, $2^{\text {nd }}$ edn (London: Faber and Faber, 1973), p. 16.

${ }^{64}$ Michael Hollington, Dickens and the Grotesque (London and Sydney: Croom Helm, 1984), p.80; p. 85.

${ }^{65}$ Paul Schlicke, Dickens and Popular Entertainment (London: Allen and Unwin,1985), p. 101; p. 128.

${ }^{66}$ John Bowen, Other Dickens: Pickwick to Chuzzlewit (Oxford: Oxford University Press, 2000), p. 132; pp. 143-56.

${ }^{67}$ Charles Dickens, Pictures from Italy (1846), ed. by Kate Flint (Harmondsworth: Penguin, 1998), p.17.

${ }^{68}$ Carey, p. 86.

${ }^{69}$ Henri Maillardet's 'Draughtsman Writer', now on display at The Franklin Institute in Philadelphia, is probably the most remarkable example of a 'resurrected' automaton. It was donated in 1928 in a dilapidated state, repaired and set in motion, whereupon it identified itself by writing 'Ecrit par L'Automate de Maillardet'. See Charles Penniman, 'Maillardet's Automaton', The Franklin Institute Science Museum $\quad<$ Hhttp://www.fi.edu/pieces/knox/automaton/home.htmH $>\quad$ and $<$ Hhttp://www.fi.edu/learn/sci-tech/automaton/automaton.php?cts=instrumentationH $>$ [accessed 20 February 2008]. A film-clip of the automaton is available at Hhttp://www.youtube.com/watch?v=jfeNC28vpYoH [accessed 8 October 2007].

${ }^{70}$ Hollington, p. 91.

${ }^{71}$ Schlicke, p. 128.

${ }^{72}$ Henri Bergson, Laughter: An Essay on the Meaning of the Comic, trans. by Cloudesley Brereton and Fred Rothwell (London: Macmillan, 1911), p. 79.

${ }^{73}$ For a contrasting appraisal of Quilp’s death see Branwen Pratt, 'Sympathy for the Devil: A Dissenting View of Quilp', Hartford Studies in Literature: A Journal of Interdisciplinary Criticism, 6:2 (1974), 12946 (p. 135). Pratt finds Quilp’s death redemptive and sympathetic, endowing him with humanity at the last.

${ }^{74}$ Michael Cotsell, 'Mr Venus Rises from the Counter: Dickens’s Taxidermist and his Contribution to Our Mutual Friend', The Dickensian, 80:2 (1984), 105-113 (p. 111).

Katherine Inglis, Becoming Automatous: Automata in The Old Curiosity Shop and Our Mutual Friend

19: Interdisciplinary Studies in the Long Nineteenth Century, 6 (2008) www.19.bbk.ac.uk 
${ }^{75}$ Albert D. Hutter, 'Dismemberment and Articulation in Our Mutual Friend', Dickens Studies Annual: Essays on Victorian Fiction, 11 (1983), 135-75 (p. 153).

${ }^{76}$ Hutter, p. 152.

${ }^{77}$ Charles Dickens, Our Mutual Friend (1864-65), ed. by Adrian Poole (London: Penguin, 1997), p. 431. Further references will be given in the text.

78 'Dolls', Household Words, 7: 168 (11 June 1853), 352-56 (p. 353) [George Dodd].

${ }^{79}$ Jürgen and Marianne Cieslik, Dolls: European Dolls 1800-1930 (London: Cassell, 1979), pp. 35-36; Mary Hillier, The History of Wax Dolls (London: Souvenir Press, 1985), pp. 59-63; Mary Hillier, Dolls and Doll-Makers (London: Weidenfeld and Nicolson, 1968), pp. 134-35; Pollock's Dictionary of English Dolls, ed. by Mary Hillier (London: Robert Hale, 1982); Mayhew, I, pp. 445-75.

80 'Dolls', Household Words, p. 354.

81 'Dolls', Household Words, p. 353.

${ }^{82}$ Hutter, p. 153.

${ }^{83}$ Bailly, p. 217.

${ }^{84}$ Sigmund Freud, 'The Uncanny', in Art and Literature, ed. by Albert Dickson, Penguin Freud Library 14 (London: Penguin, 1990), pp. 335-76 (p. 348).

${ }^{85}$ Ernst Jentsch, 'On the Psychology of the Uncanny' (1906), trans. by Roy Sellars, Angelaki, 2:1 (1995), 7-16 (p. 13).

${ }^{86}$ The Oxford Companion to the Mind, ed. by Richard L. Gregory (Oxford: Oxford University Press, 1987), p. 65.

${ }^{87}$ The Oxford Companion to the Mind, p. 66. See Jamie Croy Kassler, 'Man - a Musical Instrument: Models of the Brain and Mental Functioning Before the Computer', History of Science, 22 (1984), 59-62, for an analysis of the ubiquity of aerophones (instruments which resonate cylindrical pipes) and chordophones (instruments which resonate elastic strings, eg. the piano) as models of mental functioning prior to the advent of the computer: they were particularly important in investigations into the relation between mind and body, reflex action, and acquired automatisms such as speech.

${ }^{88}$ Richard C. Allen, David Hartley on Human Nature (Albany: SUNY, 1999), p. 169.

${ }^{89}$ Vaucanson, p. 7.

${ }^{90}$ Vaucanson, p. 16. See David M. Fryer and John C. Marshall's analysis of Vaucanson's Account for a reply to David Brewster's dismissal of Vaucanson as a mere entertainer: they read it as a serious attempt to understand human behaviour and evidence of his commitment to 'the development of an explanatory psychology’; David M. Fryer and John C. Marshall, ‘The Motives of Jacques de Vaucanson', Technology and Culture, 20:2 (1979), 257-69 (p. 268).

${ }^{91}$ See Kassler for more examples of such accounts, particularly in the study of speech articulation and automatism: Kassler suggests that though Hartley was not the first to compare the acquisition of such

Katherine Inglis, Becoming Automatous: Automata in The Old Curiosity Shop and Our Mutual Friend

19: Interdisciplinary Studies in the Long Nineteenth Century, 6 (2008) www.19.bbk.ac.uk 
higher reflex actions to learning to play a chordophone, it was his account that influenced 'the development of theories of motor automatisms': see pp. 69-70.

92 Johannes Müller, Elements of Physiology, trans. by William Baly (London: Taylor and Walton, 1842), p. 928.

${ }^{93}$ Müller, p. 939.

${ }^{94}$ Herbert Spencer, The Principles of Psychology (London: Longman, Brown, Green, and Longmans, 1855), p. 561.

${ }^{95}$ Spencer, p. 561.

${ }^{96}$ Spencer, p. 562.

${ }^{97}$ Freud, p. 366.

${ }^{98}$ Sussman and Joseph, p. 622.

${ }^{99}$ Sussman and Joseph, p. 623.

${ }^{100}$ Charles Dickens, 'Full Report of the Second Meeting of the Mudfog Association for the Advancement of Everything', Dickens' Journalism: Sketches by Boz and Other Early Papers 1833-39, ed. by Michael Slater (London: Phoenix, 1996), p. 544, first published in Bentley’s Miscellany, September 1838.

${ }^{101}$ Ovid, Metamorphoses, trans. by Mary M. Innes (Harmondsworth: Penguin, 1974), p. 232.

19: Interdisciplinary Studies in the Long Nineteenth Century, 6 (2008) www.19.bbk.ac.uk 